\title{
Determination of Trace/Toxic Mineral Risk Levels for Different Aged Consumers of Three Fish Species Caught in the Marmara Sea
}

\author{
Nuray Erkan ${ }^{1}$ (D), Muammer Kaplan² (i), Özkan Özden ${ }^{1}$ (D)
}

Cite this article as: Erkan, N., Kaplan, M., Özden, Ö. (2020). Determination of trace/toxic mineral risk levels for different aged consumers of three fish species caught in the Marmara Sea. Aquatic Sciences and Engineering, 35(1), 6-12.

ORCID IDs of the authors: N.E. 0000-0002-0752-8495 M.K. 0000-0002-8312-5479 Ö.Ö. 0000-0001-8780-480X

${ }^{1}$ Istanbul University, Faculty of Aquatic Sciences, Department of Fisheries and Seafood Processing Technology, Seafood Processing Technology Programme, Istanbul, Turkey

${ }^{2}$ TÜBITAK Marmara Research Center, Food Institute, Kocaeli, Turkey

Submitted:

09.08.2019

Revision Requested:

13.09.2019

Last Revision Received:

25.09.2019

Accepted:

11.10.2019

Online published:

28.11.2019

Correspondence:

Nuray Erkan

E-mail:

nurerkan@istanbul.edu.tr

(C) Copyright 2020 by Aquatic

Sciences and Engineering

Available online at

https://dergipark.org.tr/ase

\section{ABSTRACT}

The Marmara Sea is a semi closed fishing area in Turkey and has valuable fish species such as the common sole, black scorpionfish and horse mackerel. Domestic waste, generated by the population of over 25 million living in the coastal zone as well as industrial facilities in the region are the main causes of pollution in the Marmara Sea. In the current study, the levels of toxic metals (arsenic, cadmium, mercury, and lead) in samples of three fish tissue were analysed over a year-long period and compared with international results. The health risks for different age groups caused by the consumption of these fish were estimated. The results revealed that regular weekly consumption of sole and horse mackerel caught from the Marmara Sea posed health risks for child and youth populations. These fish species should be consumed more carefully due to potential arsenic-related hazards and carcinogenic risks for vulnerable consumer groups.

Keywords: Trace toxic mineral, HI, THQ, Health risk, The Marmara Sea, Common sole, Black scorpionfish, Horse mackerel

\section{INTRODUCTION}

Metals are one of the basic components of nature, rapid industrialization, urbanization, mining, related changes in land use and associated enhanced terrestrial runoff (to seas) with anthropogenic activities which can significantly increase their content (Bat et al. 2012; Saha et al. 2016). Biological material from aquatic sources are most easily contaminated by environmental pollution, especially due to their location in the nutritional chain. Therefore, contaminated seafoods is an important contributory factor in the transfer of environmental pollutants to consumers. Because of this reason consumption of fisheries' products is one of the main steps in the transfer of environmental pollutants to consumers. A lot of nutrient components and elements found in seafood are crucial for sustaining human life, but metals such as mercury, cadmium and lead do not play a known role in biological systems, and dietary intakes of these metals even at very low concentrations - may cause toxic effects (Storelli et al. 2012). The trace toxic minerals from sea pollutants accumulating in fish tissues are the major risk factor and therefore need to be monitored for the protection of human health. The metal toxicity associated with fish consumption depends mainly on the metal content, how often it is consumed, and on the age of the consumers (Safahieh et al. 2011). Consumption of trace toxic minerals/ contaminated fishes may result in a weakening of the endocrine system in children and adults, and these compounds have neurotoxic and nephrotoxic effects (Herreros et al. 2008).

Another important hazard rooted in environmental pollution is arsenic and its presence in seafood is an important source of arsenic exposure in humans, and according to the European Commission Scientific Cooperation Project 
(SCOOP) this ratio is may be $50 \%$ higher than other foods. Fish and shellfish are usually contaminated with arsenobetain, while arseno-lipids are found in fatty marine fish. Moreover, the inorganic form of arsenic is more toxic than organic arsenic. These compounds are genotoxic and generally have a neurotoxic effect, in the central nervous system of developing foetuses, infants and growing children (Mania et al. 2015; Koesmawatia et al. 2015).

Common sole (Solea solea) and black scorpionfish (Scorpaena porcus) are demersal fish species which do not leave their habitats, whereas horse mackerel (Trachurus trachurus) is a seasonal migratory pelagic fish in the Marmara sea. In 2017, the total production quantity of Turkey's sea fish catch was reported as 269676.4 metric tons (Turkish Statistical Institute (TUIK), 2018). The total catch was 486.4 tons for common sole, 306 tons for black scorpionfish, and 8065.6 tons for horse mackerel in Turkey. These fish species mainly live in the Marmara Sea where pollution is one of the major challenges. The domestic waste of densely populated cities (Istanbul and Izmit with a total population of nineteen million people) in the northeastern region of the Marmara Sea, maritime traffic and the waste of heavy industry plants in the Izmit Gulf are the main causes of pollution.

Fish are good indicators for the long term monitoring of metal accumulation in the marine environment. The trace toxic minerals in fish produce toxic effects at high concentrations (Keskin et al. 2007; Tepe et al. 2008; Türkmen and Ciminli, 2007). The possible health risks to consumers may vary depending on the age groups and the amount of fish consumed. In recent years, the target hazard ratio (THO) and/or total target hazard area (TTHO) have been used to assess health risks (Copat et al. 2013).

The data on trace toxic minerals levels in common sole, black scorpionfish and horse mackerel from Turkey are very limited and little information is available in the literature to quantify the health risks related with the consumption of contaminated fish from the Marmara Sea.

Therefore the main aims of the study are twofold: firstly, to determine the levels of arsenic cadmium, mercury and lead in selected fish species samples over a one-year period, and to compare the results with the limits set by International Organisations. Secondly, to assess the health risks of trace toxic minerals to consumers of different age groups.

\section{MATERIALS AND METHODS}

\section{Samples}

The common sole (Solea solea), black scorpionfish (Scorpaena porcus) and horse mackerel (Trachurus trachurus) samples (caught from the Marmara Sea) were purchased from a local fish market in Istanbul. Fish samples were collected on a monthly basis throughout the fishing season. The maximum, minimum and average of all values were presented and evaluated. Each species (10 samples for common sole, 20 samples for black scorpionfish and 100 samples for horse mackerel in each sampling) was gutted, filleted and muscle tissue was minced for analysis. The minced samples were then placed in individual polythene bags and kept frozen prior to analysis. Determination of arsenic (As), cadmium (Cd), total mercury $(\mathrm{Hg})$, and lead $(\mathrm{Pb})$ amounts in each fish species were analysed according to the Method 3051A (US Environmental protection Agency (US EPA) 2007) method.

\section{Toxic metals analysis}

Fish samples were accurately weighed (approximately $0.3 \mathrm{~g}$ ) and digested in a closed-vessel microwave digestion system (ETHOS 1, Milestone, Italy) using $6 \mathrm{~mL}$ nitric acid (65\% v/v) and $4 \mathrm{~mL}$ hydrogen peroxide (30\% v/v) (Merck, Darmstadt, Germany) at $200^{\circ} \mathrm{C}$ for $20 \mathrm{~min}$. After cooling to room temperature $\left(20-23^{\circ} \mathrm{C}\right)$, the solution was quantitatively transferred into a $25 \mathrm{~mL}$ volumetric flask and diluted to volume with ultra-pure water obtained from the Milli-O system (Millipore, Bedford, MA, USA) and stored at $4^{\circ} \mathrm{C}$ prior to analysis.

The toxic metal contents of the fishes (three sub-samples of each material) were analysed using a Thermo Scientific iCAP Qc ICPMS instrument (Thermo Fisher Scientific GmbH, Germany) equipped with an Elemental Scientific SC-2DX auto sampler (Omaha, NE, USA). The ICP-MS sample introduction system consists of a PFA concentric nebulizer coupled with a peltier-cooled cyclonic spray chamber. The iCAP Q interface consists of a pair of standard Ni sample and skimmer cones. The ICP-MS was operated in kinetic energy discrimination mode, using helium as the collision cell gas with a flow rate of $4.5 \mathrm{~mL} \mathrm{~min}^{-1}$. The following operating parameters were also set: RF power, 1,550 W; plasma gas flow rate, $14 \mathrm{~L} \mathrm{~min}^{-1}$; auxiliary gas flow rate, $0.89 \mathrm{~L} \mathrm{~min}^{-1}$; carrier gas flow rate, $0.91 \mathrm{~L} \mathrm{~min}^{-1}$; spray chamber temperature, $2.70^{\circ} \mathrm{C}$.

Arsenic, ${ }^{75} \mathrm{As}$; cadmium, ${ }^{111} \mathrm{Cd}$; mercury, ${ }^{202} \mathrm{Hg}$; and lead, ${ }^{208} \mathrm{~Pb}$ were the isotopes monitored. Quantitative analysis of the samples was performed using a five-point calibration curve $(0.5,1.0$, 2.5, 5.0, $10.0 \mu \mathrm{g} / \mathrm{L})$ constructed for each isotope. To cover the mass range of isotopes a mixture of internal standard elements $\left({ }^{6} \mathrm{Li},{ }^{45} \mathrm{Sc},{ }^{73} \mathrm{Ge},{ }^{103} \mathrm{Rh},{ }^{111} \mathrm{In},{ }^{159} \mathrm{~Tb},{ }^{175} \mathrm{Lu}\right.$ and ${ }^{209} \mathrm{Bi}$ ) at $2 \mu \mathrm{g} / \mathrm{L}$ concentration level were used. The response factors of both higher and lower mass internal standards were used to correct the concentration of each isotope monitored.

The toxic metal content results were given as $\mu \mathrm{g} / \mathrm{g}$ in wet weight (w.w.) of fish samples and the accuracy of the analytical method was monitored by analysing certified reference materials from mussel tissue (Catalogue No. ERM-CE278k).

\section{Estimation of potential public health risks}

Nine different age-categories (US Environmental protection Agency (US EPA) 2011) were used for estimating health risks: A1 1-3 years children, A2 4-6 years children, A3 7-10 years children, A4 11-14 years adolescents, A5 15-19 years adolescents, A6 2024 years adults, A7 25-54 years adults, A8 55-64 years adults and A9 $>65$ years seniors. Body weights $(\mathrm{kg})$ were $14 \mathrm{~kg}$ for $\mathrm{A} 1,21 \mathrm{~kg}$ for $\mathrm{A} 2,32 \mathrm{~kg}$ for $\mathrm{A} 3,51 \mathrm{~kg}$ for $\mathrm{A} 4,67 \mathrm{~kg}$ for $\mathrm{A} 5,72 \mathrm{~kg}$ for $\mathrm{A} 6,77$ $\mathrm{kg}$ for $\mathrm{A} 7,77 \mathrm{~kg}$ for $A 8$ and $72 \mathrm{~kg}$ for A9. The weekly fish consumption value was obtained by measuring one portion as 150 $\mathrm{g} /$ week/person for A4, A5, A6, A7, A8, A9 and $50 \mathrm{~g} /$ week/person for $A 1, A 2, A 3$. The risk assessments of the fish samples for the different groups were made according to the methods and calculations given by Erkan and Özden (2017) (Table 1). 
Table 1. Risk Assessments calculation methods

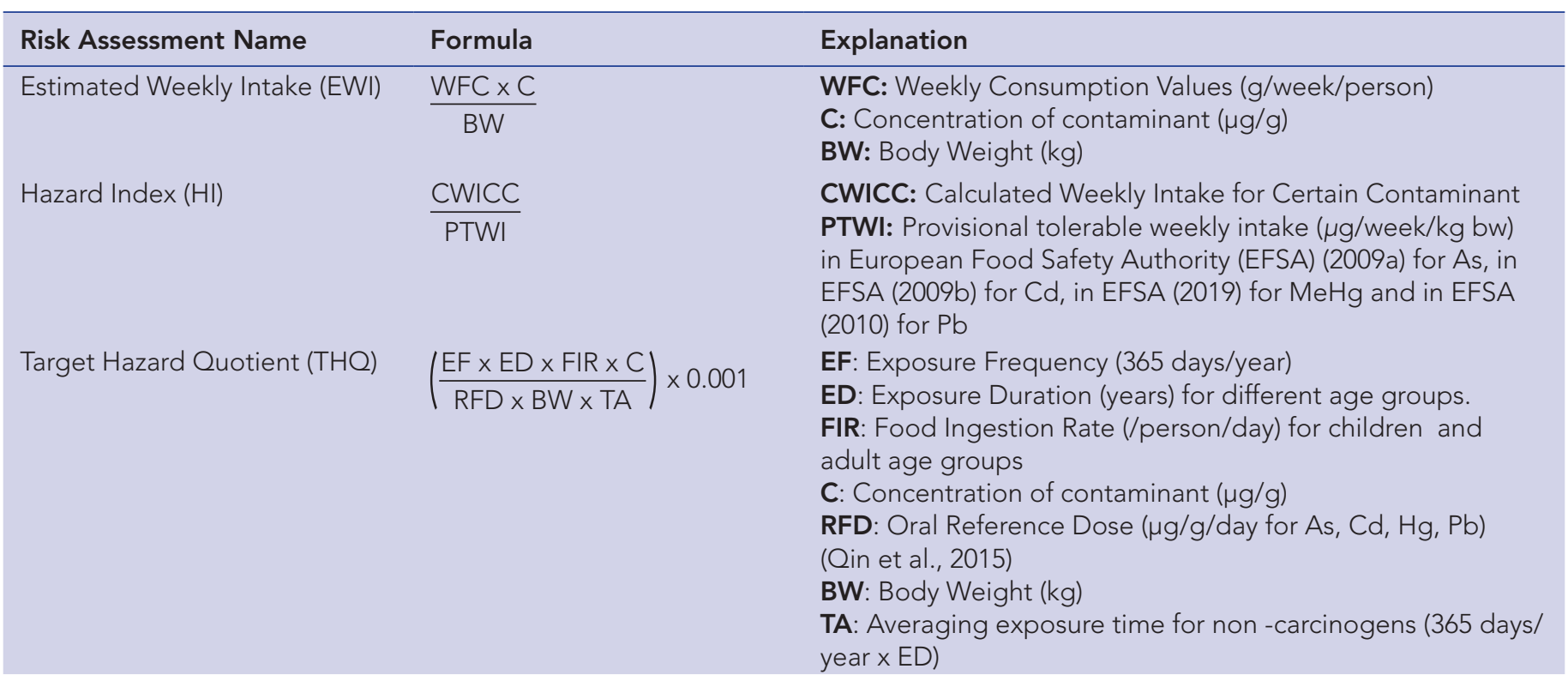

Table 2. The concentration of trace toxic minerals in three fish species of the Marmara Sea.

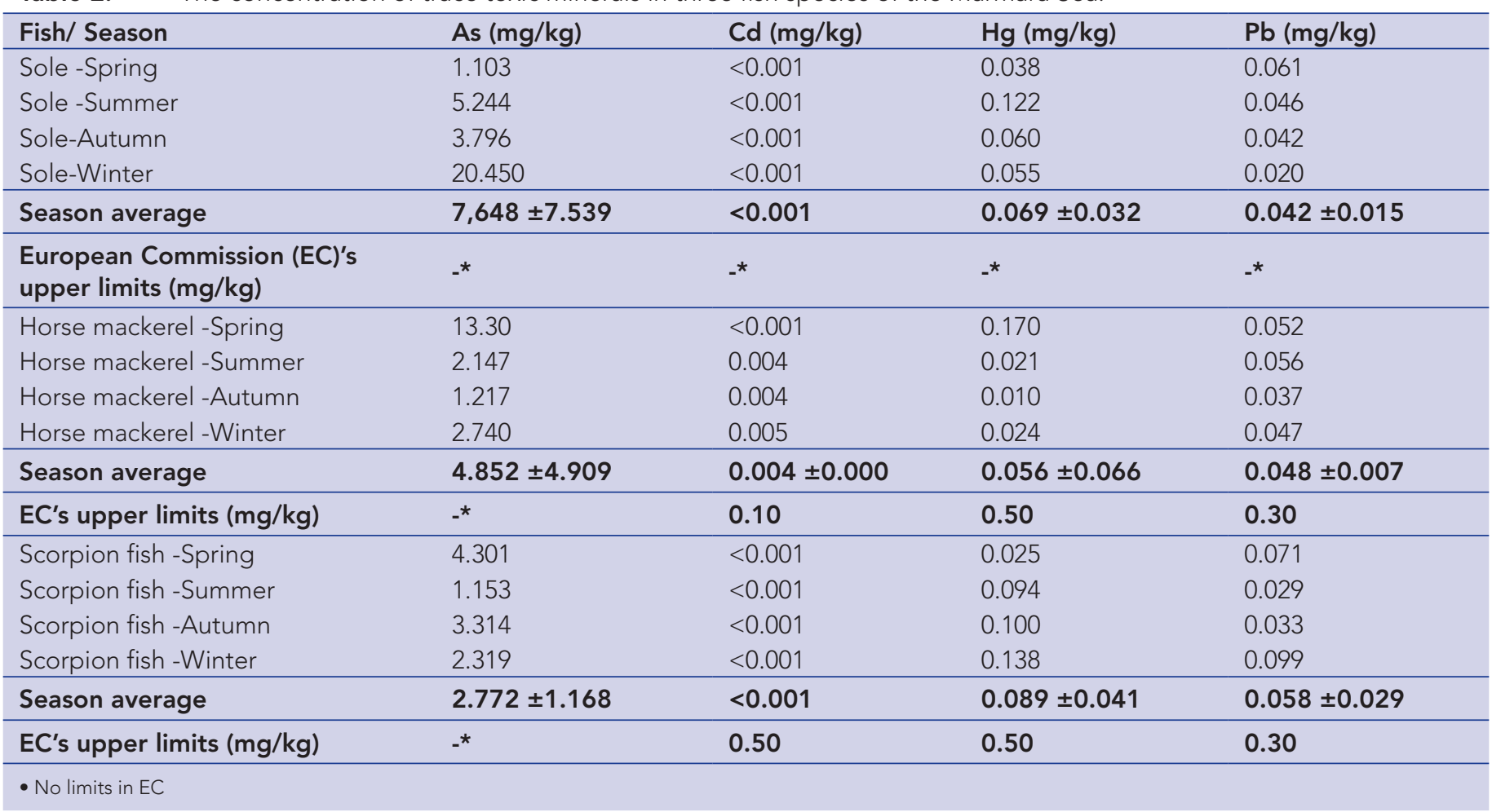

Total THQ (TTHQ) of heavy metals for seafood is the sum of the following composition: TTHQ (individual seafood) = THQ (toxicant 1) + THQ (toxicant 2) + THQ (toxicant $\mathrm{n}$ ).

The EWI, $\mathrm{HI}$ and THQ calculations of this study were conducted using 100\% Hg (EFSA, 2012) and 10\% As (Qin et al., 2015).

\section{RESULTS AND DISCUSION}

The concentration of toxic metals determined in the fish tissues are presented in Table 2. Arsenic concentration was found to be the highest of all the toxic metals measured in the three fish species studied. Arsenic toxicity depends on the form of arsenic: inorganic arsenic in drinking water is much more toxic than organic 
arsenic in seafood. The trivalent form of inorganic arsenic types is also more toxic. Arsenobetaine and arsenosugars is the major form of arsenic in marine fish and most other seafood. Arsenolipid is the form of arsenic present in fish oils and fatty fish tissue likely to be present in other seafood. According to the Turkish Food Codex (2011) there is no reported limit value for arsenic in fish and fish products. Similarly, Falcó et al. (2006) and Martorell et al. (2011) have reported high arsenic concentrations of 4.55 $\mu \mathrm{g} / \mathrm{g}$ and $11.614 \mu \mathrm{g} / \mathrm{g}$ of fresh weight in muscle tissues of sole fish from the Catalonia Region of Spain. Unlike our results, Erkan et al. (2009) and Özden et al. (2010) reported lower amounts of arsenic content in scorpion fish $(0.189-0.244 \mu \mathrm{g} / \mathrm{g})$ and sole

Table 3. Trace toxic minerals levels in literature for the three fish species.

\begin{tabular}{|c|c|c|c|c|c|c|}
\hline Sample area & Fish & As $(\mu g / g)$ & $\mathrm{Cd}(\mu \mathrm{g} / \mathrm{g})$ & $\mathrm{Hg}(\mu \mathrm{g} / \mathrm{g})$ & $\mathrm{Pb}(\mu \mathrm{g} / \mathrm{g})$ & Literature \\
\hline $\begin{array}{l}\text { Trabzon (Turkey) } \\
\text { local fish market }\end{array}$ & $\begin{array}{l}\text { Trachurus } \\
\text { trachurus }\end{array}$ & 0.63 & 3.58 & - & $<\mathrm{LOD}$ & $\begin{array}{l}\text { Aydın and } \\
\text { Tokalıoğlu, } \\
2015\end{array}$ \\
\hline \multirow[t]{2}{*}{$\begin{array}{l}\text { Coastal Waters of } \\
\text { the Black Sea, }\end{array}$} & $\begin{array}{l}\text { Trachurus } \\
\text { trachurus }\end{array}$ & - & $0.043-0.048$ & - & $0.17-0.23$ & \multirow[t]{2}{*}{ Bat et al. 2012} \\
\hline & Solea solea & - & $0.020-0.023$ & - & $0.03-0.08$ & \\
\hline Iskenderun Bay & Solea lascaris & - & 0.04 & NE & 0.39 & \multirow[t]{2}{*}{$\begin{array}{l}\text { Renieri et al. } \\
2014\end{array}$} \\
\hline Aegean Sea & $\begin{array}{l}\text { Scorpaena } \\
\text { porcus }\end{array}$ & - & 0.8 & NE & 0.66 & \\
\hline \multirow[t]{2}{*}{ Marmara Sea } & $\begin{array}{l}\text { Scorpaena } \\
\text { porcus }\end{array}$ & 0.189 & 0.001 & 0.672 & 0.007 & \multirow[t]{2}{*}{$\begin{array}{l}\text { Erkan et al. } \\
2009\end{array}$} \\
\hline & Scorpaena scrofa & 0.244 & 0.011 & 0.405 & 0.032 & \\
\hline $\begin{array}{l}\text { Varna (Bulgarian) } \\
\text { local fish market }\end{array}$ & $\begin{array}{l}\text { Trachurus } \\
\text { mediterraneus } \\
\text { ponticus) }\end{array}$ & - & 0.045 & - & 0.166 & $\begin{array}{l}\text { Stoyanova et } \\
\text { al. } 2015\end{array}$ \\
\hline Black Sea & $\begin{array}{l}\text { Trachurus } \\
\text { trachurus }\end{array}$ & - & $0.045-0.052$ & - & $0.363-0.638$ & $\begin{array}{l}\text { Yaman et al. } \\
2013\end{array}$ \\
\hline Iskenderun Bay & $\begin{array}{l}\text { Trachurus } \\
\text { mediterraneus }\end{array}$ & - & - & - & 1.037 & Yilmaz, 2003 \\
\hline \multirow{2}{*}{$\begin{array}{l}\text { Istanbul (Turkey) } \\
\text { local fish market }\end{array}$} & Solea solea & 0.34 & 0.05 & 0.56 & 0.39 & \multirow{2}{*}{$\begin{array}{l}\text { Özden and } \\
\text { Erkan, } 2016\end{array}$} \\
\hline & $\begin{array}{l}\text { Trachurus } \\
\text { trachurus }\end{array}$ & 0.25 & 0.04 & 0.29 & 0.17 & \\
\hline $\begin{array}{l}\text { Istanbul (Turkey) } \\
\text { local fish market }\end{array}$ & $\begin{array}{l}\text { Trachurus } \\
\text { trachurus }\end{array}$ & $0,026-0.644$ & $0.001-0.016$ & $0.37-1.282$ & $0.015-0.807$ & Özden, 2010 \\
\hline \multirow[t]{2}{*}{ Marmara Sea } & $\begin{array}{l}\text { Trachurus } \\
\text { mediterraneus }\end{array}$ & & 0.011 & 0.035 & 0.063 & \multirow[t]{2}{*}{$\begin{array}{l}\text { Keskin et al. } \\
2007\end{array}$} \\
\hline & Solea solea & & 0.022 & 0.329 & 0.133 & \\
\hline \multirow[t]{2}{*}{$\begin{array}{l}\text { Granada (Spain) } \\
\text { local fish market }\end{array}$} & $\begin{array}{l}\text { Trachurus } \\
\text { trachurus }\end{array}$ & 0.032 & 0.253 & 0.146 & 0.672 & \multirow[t]{2}{*}{$\begin{array}{l}\text { Rivas et al. } \\
2014\end{array}$} \\
\hline & $\begin{array}{l}\text { Trachurus } \\
\text { mediterraneus }\end{array}$ & 0.043 & 0.141 & 0.204 & 0.814 & \\
\hline $\begin{array}{l}\text { Marmara Sea } \\
\text { (Yalova) }\end{array}$ & Solea solea & - & 0.02 & - & 0.17 & \multirow[t]{4}{*}{ Türkmen, 2011} \\
\hline $\begin{array}{l}\text { North Eagean Sea } \\
\text { (Çanakkale) }\end{array}$ & & - & 0.07 & & 0.25 & \\
\hline Eagean Sea (İzmir & & - & 0.26 & - & 0.48 & \\
\hline $\begin{array}{l}\text { Meditreanean } \\
\text { (Mersin Bay) }\end{array}$ & & - & 0.38 & - & 0.37 & \\
\hline $\begin{array}{l}\text { Bulgarian Black } \\
\text { Sea coast }\end{array}$ & $\begin{array}{l}\text { Thrachurus } \\
\text { mediterraneus } \\
\text { ponticus }\end{array}$ & 0.73 & 0.008 & 0.16 & 0.06 & $\begin{array}{l}\text { Makedonski et } \\
\text { al. } 2017\end{array}$ \\
\hline $\begin{array}{l}\text { Istanbul (Turkey) } \\
\text { local fish market }\end{array}$ & Solea solea & $0.153-0.820$ & $<0.001-0.233$ & $0.135-1.858$ & $0.006-0.912$ & $\begin{array}{l}\text { Özden et al. } \\
2010\end{array}$ \\
\hline
\end{tabular}


(0.153-0.820 $\mu \mathrm{g} / \mathrm{g})$. Other researchers reported lower arsenic levels of $1.73 \mu \mathrm{g} / \mathrm{g}$ (Falcó et al. 2006), $3.141 \mu \mathrm{g} / \mathrm{g}$ (Martorell et al. 2011), 0.026-0.644 $\mu \mathrm{g} / \mathrm{g}$ (Özden, 2010), 0.032-0.043 $\mu \mathrm{g} / \mathrm{g}$ (Rivas et al. 2014), $0.63 \mu \mathrm{g} / \mathrm{g}$ (Aydın and Tokalıoğlu 2015) and $0.73 \mu \mathrm{g} / \mathrm{g}$ (Makadonski et al. 2017) in horse mackerel.

The mean concentration of $\mathrm{Cd}$ detected in sole and scorpion fish was $<0.001 \mu \mathrm{g} / \mathrm{g}$ and higher mean values of $0.004 \mu \mathrm{g} / \mathrm{g}$ wet wt. was found in horse mackerel. The $\mathrm{Cd}$ content of sole, ranging from $<0.001-0.233 \mu \mathrm{g} / \mathrm{g}$ and of horse mackerel ranging from 0.141 to $0.253 \mu \mathrm{g} / \mathrm{g}$, was reported by Özden et al. (2010) and Rivas et al. (2014). However, this value was higher (for horse mackerel $3.58 \mu \mathrm{g} / \mathrm{g}$, for scorpion fish $0.8 \mu \mathrm{g} / \mathrm{g}$, for sole $0.38 \mu \mathrm{g} / \mathrm{g}$ than that reported by other authors (Aydın and Tokalıoğlu, 2015; Renieri et al. 2014; Türkmen, 2011).

The average amounts of mercury in the tissues of the investigated species were $0.069 \pm 0.032 \mu \mathrm{g} / \mathrm{g} \mathrm{w} / \mathrm{w}$. (ranging from 0.038 $0.122), 0.056 \pm 0.066 \mu \mathrm{g} / \mathrm{g}(0.010-0.170)$ and $0.089 \pm 0.041 \mu \mathrm{g} / \mathrm{g}$ (0.025-0.138) for sole, horse mackerel and scorpion fish, respectively.
The results obtained in $\mathrm{Hg}$ content analysis of the tissue samples are similar to the results of Keskin et al. (2007) in common sole $(0.329 \mu \mathrm{g} / \mathrm{g})$; Erkan et al. (2009) in scorpion fish $(0.405-0.672 \mu \mathrm{g} / \mathrm{g})$; Rivas et al. (2014) in horse mackerel (0.146-0.204 $\mu \mathrm{g} / \mathrm{g})$.

The average lead content was found to be $0.042,0.048$ and 0.58 $\mu \mathrm{g} / \mathrm{g}$ for common sole, horse mackerel and scorpionfish respectively. In this study, Scorpionfish contained the highest lead concentration.

The lead content of sole was reported by Guérin et al. (2011) as $0.011 \mu \mathrm{g} / \mathrm{g}$. Bat et al. (2012) and Türkmen (2011) reported higher lead cocentrations of $0.03-0.08 \mu \mathrm{g} / \mathrm{g}$ and $0.17-0.48 \mu \mathrm{g} / \mathrm{g}$ in sole, respectively. In another study, even higher lead concentrations of 0.672-0.814 $\mu \mathrm{g} / \mathrm{g}$ were determined in pink salmon (Rivas et al. 2014).

The trace metal limits for the European Communities are for $\mathrm{Hg}$ $0.5 \mathrm{mg} / \mathrm{kg}(\mu \mathrm{g} / \mathrm{g})$ in fishery products, for $\mathrm{Pb} 0.3 \mathrm{mg} / \mathrm{kg}(\mu \mathrm{g} / \mathrm{g})$ in fish, for Cd $0.05 \mathrm{mg} / \mathrm{kg}(\mu \mathrm{g} / \mathrm{g})$ in lean fish, $0.1 \mathrm{mg} / \mathrm{kg}(\mu \mathrm{g} / \mathrm{g})$ in wedge sole, eel, horse mackerel, sardine, and anchovy (European Commission (EC) No 1881/2006). Unlike mercury, lead and

Table 4. $\quad \mathrm{HI}$ and $\mathrm{THO}$ risk factors for people of different ages and kilograms in three fish species from Marmara Sea.

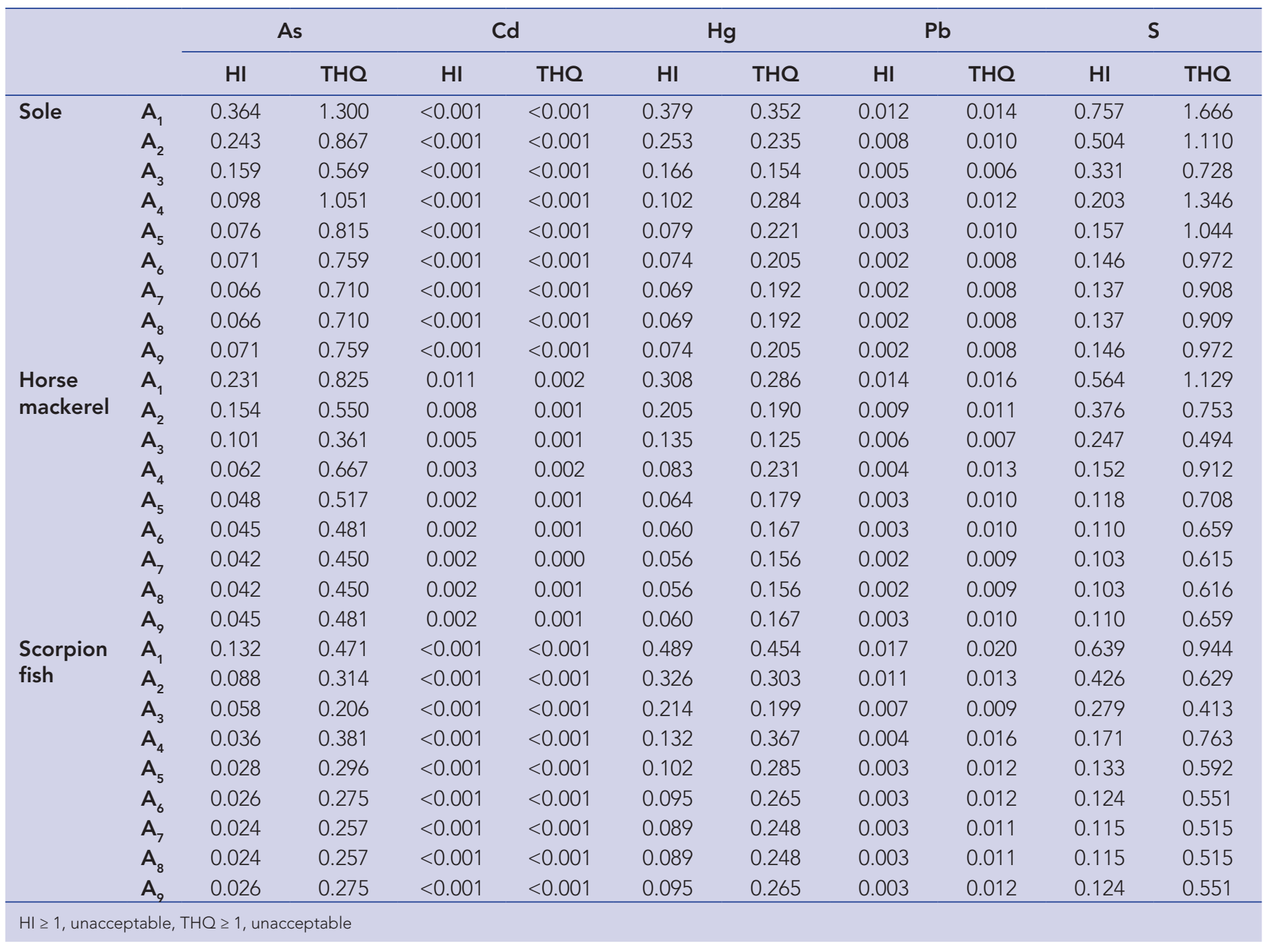


cadmium levels were considerably below the legal limits for all three fish species studied.

The hazard index, the ratio of the weekly intake value to the PTWI value for $\mathrm{As}, \mathrm{Cd}, \mathrm{Hg}$, and $\mathrm{Pb}$ calculated for different aged categories of people, was found to be well below the value of 1 $(H \mid<1)$ in all three fish species (Table 4). According to the hazard index value, consumption of these fish species for the nine different age groups does not pose any health risk. Concentrations of the contaminants in food, may cause risks to the consumer in long-term consumption even if they do not exceed legal limit values. In this process, the body weight of the consumer group and the amount of food consumed are effective in the formation of health risk. Therefore, any health risk has been estimated by making $\mathrm{THO}$ calculations in recent years. The $\mathrm{THO}$ value being equal to or higher than 1 indicates that there is a potential health risk. In this study, the THQ values calculated for the heavy metals in selected fish species showed that arsenic-derived health risks could occur for certain groups of individuals. The total THO values from consumption of sole have been found above 1 for the following age groups; A1 (1-3 years old children), A2 (4-6 years old children), A4 (11-14 years adolescents) and A5 (15-19 years adolescents) (Table 4). Also, the total THO was calculated higher than 1 for the first group consuming horse mackerel. Similar to our findings, Vieira et al. 2011 calculated the THQ value for different age groups in sardine, chub and horse mackerel collected from Portuguese waters (Northeast and Eastern Central Atlantic Ocean) during one year. They reported metal concentrations below the tolerable limits adopted by the European Commission Regulation and the United Nations Food and Agriculture Organization/World Health Organization (FAO/WHO). However, their recommendation is that the fish investigated should be consumed more carefully due to possible hazard and carcinogenic risks from arsenic. In another study, Martorell et al. (2011) reported no risk for $\mathrm{As}, \mathrm{Cd}, \mathrm{Hg}$, and $\mathrm{Pb}$ for individuals of different ages and kilograms in seafood products in Catalonia.

\section{CONCLUSIONS}

The THQ results calculated for different age groups has revealed that, due to their high arsenic content, regular weekly consumption of sole and horse mackerel from the Marmara Sea poses a health risk for the young age groups - 4-19 years old. Although there is no health risk calculated for Scorpion fish and the toxic metals studied, it is important to establish local research and toxic metal monitoring policies in the Marmara Sea fishing areas. As a result, it is recommended that periodic monitoring studies be conducted to evaluate the relationship between exposure to these toxic metals and fish and seafood consumption. It is also important that the results should be shared with the community and necessary warnings should be made in a timely manner.

Conflict of interests: The authors declare that they have no conflict of interest.

\section{REFERENCES}

Aydın, D. \& Tokalıoğlu, Ş. (2015). Trace metals in tissues of the six most common fish species in the Black Sea, Turkey. Food Additives \& Contaminants: Part B, 8(1), 25-31. [CrossRef]
Bat, L., Sezgin, M., Üstün, F., \& Şahin, F. (2012). Heavy metal concentrations in ten species of fishes caught in Sinop coastal waters of the Black Sea, Turkey. Turkish Journal of Fisheries and Aquatic Sciences, 12, 371-376.

Copat, C., Arena, G., Fiore, M., Ledda, C., Fallico, R., Sciacca, S., \& Ferrante, M. (2013). Heavy metals concentrations in fish and shellfish from eastern Mediterranean Sea: consumption advisories. Food Chemical Toxicology, 53, 33-37. [CrossRef]

European Council (EC) No 1881/2006 (2006). Setting maximum levels for certain contaminants in foodstuffs http://eur-lex.europa.eu/legalcontent/EN/TXT/PDF/?uri=CELEX:02006R1881-20140401\& rid=10 (accesed 09.09.2018).

European Food Safety Authority (EFSA) (2009a). Scientific opinion on arsenic in food. EFSA panel on contaminants in the food chain (CONTAM). EFSA Journal, 7(10), 1351. [CrossRef]

European Food Safety Authority (EFSA) (2009b). Cadmium in food. Scientific opinion of the panel on contaminants in the food chain (Question No EFSA-Q-2007-138). EFSA Journal, 980, 1-139.

European Food Safety Authority (EFSA) (2010). Scientific opinion on lead in food. EFSA panel on contaminants in the food chain (CONTAM). EFSA Journal, 8(4), 1570. [CrossRef]

European Food Safety Authority (EFSA) (2012). Scientific opinion on the risk for public health related to the presence of mercury and methylmercury in food. EFSA panel on contaminants in the food chain (CONTAM). EFSA Journal, 10(12), 2985. [CrossRef]

Erkan, N. \& Özden, Ö. (2017). Toxic metal risk with fish consumption for women of childbearing age. Journal of Food Safety and Food Quality, 68(3), 62-68.

Erkan, N., Özden, Ö., Ulusoy Ş. (2009). Levels of trace elements in commercially important fish, crustaceans and mollusks from Istanbul fish market. Fresenius Environmental Bulletin, 18(7b), 1307-1311.

Falcó, G., Llobet, J.M., Bocio, A., \& Domingo, J.L. (2006). Daily intake of arsenic, cadmium, mercury, and lead by consumption of edible marine species. Journal of Agricultural and Food Chemistry, 54, 6106-6112. [CrossRef]

Guérin, T., Chekri, R., Vastel, C., Sirot, V., Volatier, J.L., Leblanc, J.C., \& Noel L. (2011). Determination of 20 trace elements in fish and other seafood from the French market. Food Chemistry, 127(3), 934-942. [CrossRef]

Herreros, M.A., Iñigo-Nuñez, S., Sanchez-Perez, E., Encinas, T., \& Gonzales-Bulnes, A. (2008). Contribution of fish consumption to heavy metals exposure in women of childbearing age from a Mediterranean country (Spain). Food and Chemical Toxicology, 46, 1591-1595. [CrossRef]

Keskin, Y., Baskaya, R., Özyaral, O., Yurdun, T., Lüleci, N.E., \& Hayran, O. (2007). Cadmium, lead, mercury and copper in fish from the Marmara Sea, Turkey. Bulletin of Environmental Contamination and Toxicology, 78, 258-261. [CrossRef]

Koesmawatia, T.A., Buchari, B., Sulaeman, A., \& Ibrahim, S. (2015). Sample preparation methods for organic arsenic species (arsenobetain, $\left.\left(\mathrm{CH}_{3}\right)_{3} \mathrm{As}+\mathrm{CH}_{2} \mathrm{COO}-\right)$ in tuna fish samples followed by HG-QFAAS, GF-AAS, and ICP-MS measurements. Procedia Chemistry, 17, 200206. [CrossRef]

Makedonski, L., Peycheva, K., \& Stancheva, M. (2017). Determination of heavy metals in selected black sea fish species. Food Control, 72, 313-318. [CrossRef]

Mania, M., Rebeniak M, Szynal, T., Wojciechowska-Mazurek, M., Starska, K., Ledzion, E., \& Postupolski, J. (2015). Total and inorganic arsenic in fish, seafood and seaweeds - exposure assessment. Roczniki Panstwowego Zakladu Higieny, 66(3), 203-210.

Martorell, I., Perelló, G., Martí-Cid, R., Llobet, J.M., Castell, V., \& Domingo, J.L. (2011). Human exposure to arsenic, cadmium, mercury, and lead from foods in Catalonia, Spain: temporal trend. Biological Trace Element Research, 142, 309-322. [CrossRef] 
Özden, Ö. (2010). Micro, macro mineral and proximate composition of Atlantic bonito and horse mackerel: a monthly differentiation. International Journal of Food Science \& Technology, 45, 578-586. [CrossRef]

Özden, Ö. \& Erkan, N. (2016). Evaluation of risk characterization for mercury, cadmium, lead and arsenic associated with seafood consumption in Turkey. Exposure and Health, 8, 43-52. [CrossRef]

Özden, Ö., Erkan, N., \& Ulusoy, Ş. (2010). Determination of mineral composition in three commercial fish species (Solea solea, Mullus surmuletus, and Merlangius merlangus). Environmental Monitoring and Assessment, 170, 353-363. [CrossRef]

Qin, D., Jiang, H., Bai, S., Tang. S., \& Mou, Z. (2015). Determination of 28 trace elements in three farmed cyprinid fish species from Northeast China. Food Control, 50, 1-8. [CrossRef]

Renieri, E.A., Alegakis, A.K., Kiriakakis, M., Vinceti, M., Ozcagli, E., Wilks, M.F., \& Tsatsakis, A.M. (2014). Cd, Pb and Hg biomonitoring in fish of the Mediterranean region and risk estimations on fish consumption. Toxics, 2, 417-442. [CrossRef]

Rivas, A., Peña-Rivas, L., Ortega, E., López-Martínez, C., OleaSerrano, F., Lorenzo, M.L. (2014). Mineral element contents in commercially valuable fish species in Spain. Scientific World Journal, 2014: 1-7. [CrossRef]

Saha, N., Mollah, M.Z.I., Alam, M.F., \& Safiur Rahman, M. (2016). Seasonal investigation of heavy metals in marine fishes captured from the Bay of Bengal and the implications for human health risk assessment. Food Control, 70, 110-118. [CrossRef]

Safahieh, A., Monikh, F.A., \& Savari, A. (2011). Heavy metals contamination in sediment and Sole fish (Euryglossa orientalis) from Musa Estuary (Persian Gulf). World Journal of Fish and Marine Sciences, 3(4), $290-$ 297.

Storelli, M.M., Normanno, G., Barone, G., Dambrosio, A., Errico, L., Garofalo, R., \& Giacominelli-Stuffler, R. (2012). Toxic metals (Hg, Cd and $\mathrm{Pb}$ ) in fishery products imported into Italy: Suitability for human consumption. Journal of Food Protection, 75, 189-194. [CrossRef]

Stoyanova, S., Sirakov, I., Velichkova, K., \& Staykov, Y. (2015). Chemical composition and content of heavy metals in the flesh of the different marine fish species. Journal of BioScience and Biotechnology, Special Edition, 297-301.
Tepe, Y., Türkmen, M., \& Türkmen, A. (2008). Assessment of heavy metals in two commercial fish species of four Turkish seas. Environmental Monitoring and Assessment, 46, 277-284. [CrossRef]

Turkish Statistical Institute (TUIK) (2018). Avlanan deniz balıkları miktarı Quantity of caught sea fish, http://www.tuik.gov.tr/PrelstatistikTablo. do?istab_id=693 (accessed 11.10.18).

Turkish Food Codex (2011). Regulation amending the Turkish food codex regulation on contaminants in foodstuffs. http://faolex.fao.org/docs/ texts/tur110178.doc (accessed 15.10.18).

Türkmen, A. (2011). Türkiye denizleri'nden yakalanan dil balığı (Solea solea L., 1758) türünün kas ve karaciğer dokularında ağır metal düzeylerinin belirlenmesi. Karadeniz Fen Bilimleri Dergisi, 1(3), 139151.

Türkmen, M. \& Ciminli, C. (2007). Determination of metals in fish and mussel species by inductively coupled plasma-atomic emission spectrometry. Food Chemistry, 103, 670-675. [CrossRef]

US Environment protection Agency (US EPA) (2007). Microwave assisted acid digestion of sediments, sludges, soils, and oils. Method 3051A (Revision 1 February 2007). https://www.epa.gov/sites/production/ files/2015-12/documents/3051a.pdf (accessed 05.06.16).

US Environment protection Agency (US EPA) (2011). Exposure factors handbook: 2011 Edition. EPA/600/R-090/052F, September 2011, http://ofmpub.epa.gov/eims/eimscomm.getfile?p_download_ $\mathrm{id}=522996$ (accessed 29.08.18).

Vieira, C., Morais, S., Ramos, S., Delerue-Matos, C., \& Oliveira, M.B.P.P. (2011). Mercury, cadmium, lead and arsenic levels in three pelagic fish species from the Atlantic Ocean: Intra- and inter-specific variability and human health risks for consumption. Food and Chemical Toxicology, 49(4), 923-932. [CrossRef]

Yaman, M., Bal, T., \& Yaman, I.H. (2013). Metal levels in Trachurus trachurus and Cyprinus carpio in Turkey. Food Additives \& Contaminants: Part B, 6(4), 301-306. [CrossRef]

Yılmaz, A.B. (2003). Levels of heavy metals ( $\mathrm{Fe}, \mathrm{Cu}, \mathrm{Ni}, \mathrm{Cr}, \mathrm{Pb}$, and $\mathrm{Zn}$ ) in tissue of Mugil cephalus and Trachurus mediterraneus from Iskenderun Bay, Turkey. Environmental Research, 92, 277-281. [CrossRef] 